\title{
PERSEPSI MAHASISWA PADA PELAKSANAAN KURIKULUM PROGRAM MAGISTER PENDIDIKAN SOSIOLOGI
}

\author{
Eskiel Marodama ${ }^{1}$, Simeon Hatta ${ }^{2}$ \\ ${ }^{1}$ SMA Negeri 1 Simpang Hulu, Ketapang, Kalimantan Barat, Indonesia. \\ e-mail korespondensi: eskielmarodama@gmail.com
}

\begin{abstract}
Abstrak : Tujuan penelitian ini adalah untuk mengetahui persepsi mahasiswa terhadap pelaksanaan kurikulum, baik itu tentang muatan kurikulum, penyelenggaraan kurukulum dan evalusi proses pembelajaran. Metode yang digunakan adalah metode kuantitatif dan bentuk penelitian adalah survey. Hasil penelitian ini menunjukkan bahwa (1) persepsi mahasiswa terhadap muatan kurikulum pendidikan tinggi yang diselenggarakan oleh Program Magister Pendidikan Sosiologi FKIP UNTAN sebesar 21,78\% dari total skor sebesar 25, menunjukkan rata-rata mahasiswa setuju terhadap muatan kurikulum pendidikan tinggi yang dilaksanakan, (2) persepsi mahasiswa terhadap penyelenggaraan kurikulum pendidikan tinggi yang diselenggarakan oleh Program Magister Pendidikan Sosiologi FKIP UNTAN sebesar 21,44\% dari nilai total skor sebesar 25 , menunjukkan rata-rata mahasiswa setuju terhadap muatan kurikulum pendidikan tinggi yang dilaksanakan, (3) persepsi mahasiswa terhadap evaluasi proses pembelajaran pendidikan tinggi yang diselenggarakan oleh Program Magister Pendidikan Sosiologi FKIP UNTAN sebesar 88,4\% dari toal skor sebesar 86, menunjukkan rata-rata mahasiswa setuju terhadap evaluasi proses pembelajaran pendidikan tinggi yang dilaksanakan.
\end{abstract}

Kata kunci: Persepsi Mahasiswa, Pelaksanaan Kurikulum

\begin{abstract}
The purpose of this study was to determine students' perceptions of the implementation of the curriculum, be it about the curriculum, implementation and evaluation kurukulum learning process. The method used is quantitative method and form of research is the survey. The results of this study indicate that (1) the perception of students towards higher education curriculum that is organized by the Master Program in Sociology of Education FKIP UNTAN for $21.78 \%$ of the total score of 25, showed that the average student agrees to the curriculum of higher education conducted, (2) students 'perceptions of the organization of higher education curriculum that is organized by the Master Program in Sociology of Education FKIP UNTAN for $21.44 \%$ of the total score of 25, showed that the average student agrees to the curriculum of higher education conducted, (3) students' perceptions evaluation of higher education learning process organized by the Master Program Sociology Education FKIP UNTAN for $88.4 \%$ of the toal score of 86 , showed that the average student agrees to the evaluation of higher education learning process is implemented.
\end{abstract}

Keyword: Perception of Students, Curriculum Implementation.

\section{PENDAHULUAN}

Pendidikan merupakan ujung tombak dalam mempersiapkan sumber daya manusia yang handal. Pendidikan diyakini dapat memaksimalkan potensi mahasiswa untuk dapat bersikap kritis, logis dan inovatif dalam menyelesaikan setiap permasalahan yang dihadapinya. Salah satu hal yang dilakukan manusia untuk memperoleh pendidikan adalah dengan mengikuti pendidikan formal. Pendidikan formal adalah jalur pendidikan yang terstruktur dan berjenjang yang terdiri atas pendidikan anak usia dini, pendidikan dasar, pendidikan menengah, dan pendidikan tinggi. Pendidikan formal terdiri dari pendidikan formal berstatus negeri dan pendidikan formal berstatus swasta (Suryabrata, 2005).

Pengelolaan Pembelajaran merupakan proses untuk mencapai tujuan pembelajaran. Untuk mencapai tujuan pembelajaran diperlukan proses panjang yang dimulai 
dengan perencanaan, pengorganisasian dan penilaian. Perencanaan meliputi kegiatan menetapkan apa yang ingin dicapai, bagaimana mencapai, waktu dan personel yang diperlukan. Sedang pengorganisasian merupakan pembagian tugas kepada personel yang terlibat dalam usaha mencapai tujuan pembelajaran, pengkoordinasian, pengarahan dan pemantauan. Evaluasi sebagai proses dilaksanakan untuk mengetahui ketercapaian tujuan yang telah dicanangkan, faktor pendukung dan penghambatnya. (Syaifurahman \& Tri Ujiati, 2013).

Penyelenggaraan pendidikan pada program Magister Pendidikan Sosiologi berdasarkan Surat Keputusan Dirjen Dikti Nomor: 331/E.E2/DT/2014, tanggal 8 April 2014, tentang Pemberian Mandat Penyelenggaraan Program Studi Pendidikan Sosiologi di Untan Pontianak. Tujuannya menyiapkan dan meningkatkan kualitas sumber daya manusia Indonesia di Kalimantan Barat dan sekitarnya dan untuk meningkatkan Angka Partisipasi Kasar (APK) Pendidikan Tinggi di Indonesia. Program studi ini juga dilaksanakan untuk mempersiapkan tenaga guru dan ahli pendidikan yang profesional dalam pengajaran Sosiologi dan Ilmu Sosial untuk jenjang pendidikan menengah (SMU/SMK/MA). Program studi ini juga diharapkan dapat meningkatkan kualitas sumber daya manusia dari berbagai Dinas/Instansi Pemerintah maupun Swasta, dapat mempersiapkan praktisi di berbagai instansi yang mampu memahami dan memberikan solusi atas gejala-gejala dan masalah-masalah sosial di era global. Sesuai dengan visi dan misi program Magister Pendidikan Sosiologi sebagai berikut:

VISI : Pada tahun 2025 menjadi Program Studi S2 Pendidikan Sosiologi terkemuka di Indonesia, pelopor pembaharuan pemikiran dan pelaksana pembinaan kehidupan insan yang jujur, cerdas, berahklak mulia, yang mampu mewujudkan Tri Dharma Perguruan Tinggi (Pendidikan dan Pengajaran, Penelitian dan Pengabdian Kepada Masyarakat).

MISI : Menghasilkan magister pendidikan sosiologi dan mengembangkan Sumber Daya Manusia yang kompeten, handal dan profesional untuk memenuhi peluang kerja di tingkat lokal, nasional dan global.

Dalam penyusunan kurikulum yang sering dilakukan setelah didapat hasil dari analisis hal-hal tersebut adalah menentukan tujuan pendidikan. Tujuan pendidikan inilah yang kemudian segera dijabarkan dalam mata kuliah yang kemudian dilengkapi dengan bahan ajarnya (silabus) untuk setiap mata kuliah. Sejumlah mata kuliah ini disusun kedalam semester-semester. Penyusunan mata kuliah ke dalam semester biasanya didasarkan pada struktur atau logika urutan pembangunan dan perkembangan imu pengetahuan, teknologi dan seni IPTEKS yang dipelajari, berdasarkan urutan tingkat kerumitan dan kesulitan ilmu yang dipelajari. Kurikulum semacam ini yang sering disebut kurikulum berbasis isi (content based curriculum). Dalam hal ini dipertimbangkan apakah lulusannya nanti relevan dengan kebutuhan masyarakat pemangku kepentingan (stakeholders) atau tidak.

Pelaksanaan kurikulum sangat dipengaruhi oleh sumber daya manusia yang ada yaitu dosen, sarana prasarana dan manajemen keuangan. Dosen merupakan faktor yang paling berperan karena melalui dosenlah pelaksanaan kurikulum dapat berjalan dengan efektif. Peran dosen dalam penerapan kurikulum harus disertai dengan semakin meningkatnya kemampuan dosen dalam pengelolaan pembelajaran. Kemampuan dosen dalam pengelolaan pembelajaran akan mempengaruhi kemampuan mahasiswa dalam menerima pelajaran yang diberikan sehingga pada saat dilaksanakan evaluasi diharapkan mahasiswa dapat memperoleh nilai yang memuaskan. (Sutikno, 2009).

Proses pembelajaran yang banyak dipraktekkan sekarang ini sebagian besar berbentuk penyampaian secara tatap muka (lecturing), searah. Pada saat mengikuti kuliah atau mendengarkan ceramah, mahasiswa akan kesulitan untuk mengikuti atau menangkap makna esensi materi pembelajaran, sehingga kegiatannya sebatas membuat catatan. Pola proses pembelajaran dosen aktif dengan mahasiswa pasif ini efektifitasnya rendah, dan tidak dapat menumbuhkembangkan proses partisipasi aktif dalam pembelajaran. Keadaan ini terjadi sebagai akibat elemen-elemen terbentuknya proses partisipasi yang berupa, (i) dorongan untuk memperoleh harapan (effort), (ii) kemampuan mengikuti proses pembelajaran, dan (iii) peluang untuk mengungkapkan materi pembelajaran yang diperolehnya di dunia nyata/masyarakat tidak 
ada atau sangat terbatas. Intensitas pembelajaran mahasiswa umumnya meningkat (tetapi tetap tidak efektif), terjadi pada saatsaat akhir mendekati ujian. Akibatnya mutu materi dan proses pembelajaran sangat sulit untuk diases. Dosen menjadi pusat peran dalam pencapaian hasil pembelajaran dan seakan-akan menjadi satu-satunya sumber ilmu. Perbaikan pola pembelajaran ini telah banyak dilakukan dengan kombinasi lecturing, tanya-jawab, dan pemberian tugas, yang kesemuanya dilakukan berdasarkan "pengalaman mengajar" dosen yang bersangkutan dan bersifat trial-error. Luaran proses pembelajaran tetap tidak dapat diases, serta memerlukan waktu lama pelaksanaan perbaikannya.

Berdasarkan uraian singkat latar belakang masalah yang telah dikemukakan di atas, maka rumusan masalah dalam penelitian ini adalah: "Bagaimana Persepsi Mahasiswa Pada Pelaksanaan Kurikulum Program Magister Pendidikan Sosiologi di FKIP Universitas Tanjungpura Pontianak?". Mengingat permasalahan yang dikemukakan diatas masih bersifat umum, maka dipandang perlu untuk membatasinya ke dalam sub-sub masalah, (1) Bagaimana muatan kurikulum pendidikan tinggi pada program Magister Pendidikan Sosiologi FKIP Universitas Tanjungpura Pontianak?, (2) Bagaimana penyelenggaraan kurikulum pendidikan tinggi pada program Magister Pendidikan Sosiologi FKIP Universitas Tanjungpura Pontianak?, (3) Bagaimana proses pelaksanaan pendidikan dan pengajaran pada program Magister Pendidikan Sosiologi FKIP Universitas Tanjungpura Pontianak?.

\section{METODE}

Metode yang digunakan adalah metode kuantitatif dan bentuk penelitian adalah survey, dengan analisis deskriptif.

Populasi adalah keseluruhan objek penelitian yang akan diteliti (Notoatmodjo, 2010). Populasi dalam penelitian ini adalah seluruh mahasiswa program Magister Pendidikan Soiologi di FKIP Universitas Tanjungpura Pontianak periode tahun 2015 sebanyak 9 mahasiswa. Sampel adalah bagian dari jumlah dan karakteristik yang dimiliki oleh populasi (Sopiyudin, 2010). Sampel dalam penelitian ini sebanyak 9 sampel mahasiswa.

\section{Teknik dan Alat Pengumpul Data}

Sehubungan dengan pendekatan penelitian yang digunakan tim peneliti adalah pendekatan kuantitatif, maka pengumpul data yang digunakan lebih ditekankan pada penggunaan teknik pengumpulan data dengan komunikasi tidak langsung dan instrument penelitian yang digunakan berupa kuesioner (angket).

Untuk melengkapi teknik komunikasi tidak langsung berupa angket, peneliti juga menggunakan dokumentasi dari administrasi akademik FKIP UNTAN Pontianak yang berkaitan dengan mahasiswa program Magister Pendidikan Sosiologi sebagai sampelnya.

Dalam penelitian ini peneliti menggunakan metode angket tertutup secara langsung yaitu responden harus memiliki jawaban yang tersedia di dalam angket, mengenai bentuk angket yang digunakan adalah sistem pilihan jawaban. Penilaian angket menggunakan skala likert 1 sampai 5, sebagai berikut:

a) Jawaban sangat setuju diberi nilai 5

b) Jawaban setuju diberi 4

c) Jawaban cukup setuju diberi nilai 3

d) Jawaban tidak setuju diberi nilai 2

e) Jabatan sangat tidak setuju diberi nilai 1

Mengingat penelitian ini bersifat penelitian formal atau melalui pendekatan kuantitatif maka peneliti menggunakan teknik pengolahan dan analisis data penelitian secara kuantitatif dengan bantuan statistik melalui program SPSS versi 20, dengan teknik analisis frekuensi dan deskripsi. Penggunaan statistik dengan analisis frekuensi dan deskripsi ini tetap memperhatikan persyaratan asumsi klasik yang harus dipenuhi sebelum melakukan analisis data penelitian.

\section{HASIL DAN PEMBAHASAN Hasil Penelitian}

Terdapat empat indikator dalam penelitian ini yaitu tentang muatan kurikulum, penyelenggaraan kurikulum, evaluasi proses pembelajaran dan proses pendidikan dan pengajaran. Untuk mendeskripsikannya maka pada bagian ini disajikan deskripsi data dari masing-masing indikator berdasarkan data yang diperoleh dari tempat penelitian. Obyek penelitian ini adalah mahasiswa program Magister Pendidikan Sosiologi angkatan tahun 2020 (semester 3) dengan jumlah responden 9 orang.

Setelah dilakukan penyebaran kuesioner pada mahasiswa program Magister Pendidikan 
Sosiologi angkatan tahun 2020 (semester 3), kemudian dilakukan perhitungan dengan menggunakan program software SPSS versi 20 for windows. Untuk memperoleh informasi tentang bagaimana persepsi mahasiswa terhadap pelaksanaan kurikulum pada program Magister Pendidikan Sosiologi, disebarkan angket dengan 5 (lima) alternatif jawaban dapat dipilih oleh mahasiswa sesuai dengan persepsinya sendiri. Alternatif jawaban tersebut Sangat Setuju (76\%-100\%), Setuju (51-75\%), Cukup Setuju (26-50\%), Tidak Setuju (1-25\%) dan Sangat Tidak Setuju (0\%).

Deskripsi Data Persepsi Mahasiswa Program Magister Pendidikan Sosiologi Tentang Muatan Kurikulum

Berikut akan dijelaskan bagaimana gambaran persepsi mahasiswa program Magister Pendidikan Sosiologi tentang muatan kurikulum berdasarkan indikator yang telah dijabarkan dalam angket pernyataan penelitian. Indikator persepsi mahasiswa mengenai muatan kurikulum dibagi atas 5 pernyataan. Dalam pengukuran angket, peneliti menggunakan skala likert dengan lima pilihan jawaban. Berikut ditampilkan hasil memberikan deskripsi sebaran persepsi mahasiswa terhadap pelaksanaan kurikulum melalui muatan kurikulum pada setiap program pengembangan kurikulum.

\section{Deskripsi Data Persepsi Mahasiswa Program Magister Pendidikan Sosiologi Tentang Penyelenggaraan Kurikulum}

Berikut akan dijelaskan bagaimana gambaran persepsi mahasiswa program Magister Pendidikan Sosiologi tentang penyelenggaraan kurikulum berdasarkan indikator yang telah dijabarkan dalam angket pernyataan penelitian. Indikator persepsi mahasiswa mengenai muatan kurikulum dibagi atas 5 pernyataan. Dalam pengukuran angket, peneliti menggunakan skala likert dengan lima pilihan jawaban. Berikut ditampilkan hasil memberikan deskripsi sebaran persepsi mahasiswa terhadap pelaksanaan kurikulum melalui penyelenggaraan kurikulum pada setiap program pengembangan kurikulum. Berikut ditampilkan hasil deskripsi sebaran persepsi mahasiswa terhadap penyelenggaraan kurikulum dalam pelaksanaan kegiatan belajar mengajar.

\section{Deskripsi Data Persepsi Mahasiswa Program Magister Pendidikan Sosiologi Tentang Penyelenggaraan Kurikulum}

Berikut akan dijelaskan bagaimana gambaran persepsi mahasiswa program Magister Pendidikan Sosiologi tentang penyelenggaraan kurikulum berdasarkan indikator yang telah dijabarkan dalam angket pernyataan penelitian. Indikator persepsi mahasiswa mengenai evaluasi proses pembelajran dibagi atas 21 pernyataan. Dalam pengukuran angket, peneliti menggunakan skala likert dengan lima pilihan jawaban. Berikut ditampilkan hasil memberikan deskripsi sebaran persepsi mahasiswa terhadap pelaksanaan kurikulum melalui evaluasi proses pembelajaran pada setiap program pengembangan kurikulum. Berikut ditampilkan hasil deskripsi sebaran persepsi mahasiswa terhadap evaluasi proses pembelajaran dalam pelaksanaan kegiatan belajar mengajar.

\section{Pembahasan}

Berdasarkan hasil penelitian yang telah dikemukakan sebelumnya, maka pembahasan untuk menjawab pertanyaan dalam rumusan masalah adalah sebagai berikut:

Muatan Kurikulum Pendidikan Tinggi Pada Program Magister Pendidikan Sosiologi FKIP Universitas Tanjungpura Pontianak.

Berdasarkan dari uraian hasil pengolahan data secara statistik deskriptif, nilai rata-rata (mean) dari hasil angket sebesar 21,78 dari total nilai jawaban angket sebesar 25. Ini menunjukkan bahwa secara rata-rata jawaban responden yang merupakan mahasiswa Program Magister Pendidikan Sosiologi sangat setuju dengan pernyataan yang disajikan dalam angket yang berkaitan dengan indikator muatan kurikulum pada pendidikan tinggi.

Maka dari itu dapat disimpulkan bahwa dari hasil angket ini diketahui bahwa mahasiswa Program Magister Pendidikan Sosiologi rata-rata setuju dengan konten muatan kurikulum pendidikan tinggi yang dilaksanakan oleh program Magister Pendidikan Sosiologi FKIP Universitas Tanjungpura. 


\section{Penyelenggaraan Kurikulum Pendidikan Tinggi Pada Program Magister Pendidikan Sosiologi FKIP Universitas Tanjungpura Pontianak.}

Berdasarkan dari uraian hasil pengolahan data secara statistik deskriptif, nilai rata-rata (mean) dari hasil angket sebesar 21,44 dari total nilai jawaban angket sebesar 25 . Ini menunjukkan bahwa secara rata-rata jawaban responden yang merupakan mahasiswa Program Magister Pendidikan Sosiologi sangat setuju dengan pernyataan yang disajikan dalam angket yang berkaitan dengan indikator penyelenggaraan kurikulum pendidikan tinggi.

Maka dari itu dapat disimpulkan bahwa dari hasil angket ini diketahui bahwa mahasiswa Program Magister Pendidikan Sosiologi rata-rata setuju dengan konten penyelenggaraan kurikulum pendidikan tinggi yang dilaksanakan oleh program Magister Pendidikan Sosiologi FKIP Universitas Tanjungpura.

Evaluasi Proses Pembelajaran Pada Program Magister Pendidikan Sosiologi FKIP Universitas Tanjungpura Pontianak?

Berdasarkan dari uraian hasil pengolahan data secara statistik deskriptif, nilai rata-rata (mean) dari hasil angket sebesar 88,44 dari total maksimal nilai total angket sebesar 86 . Ini menunjukkan bahwa secara rata-rata jawaban responden yang merupakan mahasiswa Program Magister Pendidikan Sosiologi sangat setuju dengan pernyataan yang disajikan dalam angket yang berkaitan dengan indikator evaluasi proses pembelajaran dan pengajaran dan pendidikan.

Maka dari itu dapat disimpulkan bahwa dari hasil angket ini diketahui bahwa mahasiswa Program Magister Pendidikan Sosiologi rata-rata setuju dengan adanya evaluasi proses pembelajaran dalam muatan kurikulum pendidikan tinggi.

\section{SIMPULAN}

Berdasarkan hasil pengujian hasil data angket secara deskriptif dan pembahasan yang telah diuraikan, maka ditarik kesimpulan khusus dari penelitian ini sebagai berikut: Muatan kurikulum pendidikan tinggi yang diselenggarakan oleh Program Magister Pendidikan Sosiologi FKIP Universitas
Tanjungpura mendapat melalui 5 pernyataan yang diberikan dalam angket, persepsi mahasiswa sebagai responden mendapatkan skor 21,78 dari nilai total skor sebesar 25 . Maka dapat dikatakan persepsi mahasiswa rata-rata setuju terhadap muatan kurikulum pendidikan tinggi yang dilaksanakan oleh Program Magister Pendidikan Sosiologi FKIP Universitas Tanjungpura. Penyelenggaraan Pembelajaran pendidikan tinggi yang diselenggarakan oleh Program Magister Pendidikan Sosiologi FKIP Universitas Tanjungpura mendapat melalui 5 pernyataan yang diberikan dalam angket, persepsi mahasiswa sebagai responden mendapatkan skor 21,44 dari nilai total skor sebesar 25 . Maka dapat dikatakan persepsi mahasiswa rata-rata setuju terhadap muatan kurikulum pendidikan tinggi yang dilaksanakan oleh Program Magister Pendidikan Sosiologi FKIP Universitas Tanjungpura. Evaluasi Proses Pembelajaran pendidikan tinggi yang diselenggarakan oleh Program Magister Pendidikan Sosiologi FKIP Universitas Tanjungpura mendapat melalui 18 pernyataan yang diberikan dalam angket, persepsi mahasiswa sebagai responden mendapatkan skor 88,4 dari nilai total skor sebesar 86. Maka dapat dikatakan persepsi mahasiswa rata-rata setuju terhadap evaluasi proses pembelajaran pendidikan tinggi yang dilaksanakan oleh Program Magister Pendidikan Sosiologi FKIP Universitas Tanjungpura.

DAFTAR RUJUKAN

Robbins, S. P. (2006). Organization Behavior. Dalam B. Molan, Perilaku Organisasi. Jakarta: PT Indeks.

Sopiyudin. (2010). Besar Sampel Dan Cara Pengambilan Sampel Dalam Penelitian. Jakarta : Penerbit Salemba Medika.

Suryabrata, S. (2005). Psikologi Pendidikan. Jakarta: Rajawali Pers.

Sutikno, M. S. (2009). Belajar Dan Pembelajaran; Upaya Kreatif Dalam Mewujudkan Pembelajaran Yang Kreatif. Jakarta: Prospek.

Widayatun, T. R. (1999). Ilmu Perilaku. Jakarta: Seagung Seto 